\title{
THE PRACTICE OF HIBAH AS A SUBSTITUTE HEIR AMONG THE JAVANESE FAMILY
}

\author{
Sukiati \\ Universitas Islam Negeri Sumatera Utara Medan \\ Jl. Williem Iskandar Pasar V, Medan Estate, Medan, Sumatera Utara, 20371 \\ e-mail: sukiatisugiono@gmail.com
}

\begin{abstract}
This paper is an attempt to discuss the tradition of bequest or hibah as an inheritance, in which the wealth is distributed before the parents passed away among Javanese Family in Selesai Langkat. Data collection used qualitative method and phenomenology approach. Data analysis used descriptive analysis. The data from the field was collected, processed, reduced and then concluded. It is concluded that there are three patterns of giving hibah: the first, the treasure is granted entirely to the heirs before the heirs passed away. The surviving heir is usually set aside for living expenses and needs. The heir is usually living with the youngest child called, the 'ragil.' When he dies, the child who tookcare will inherit the wealth. Second, inheritance is distributed after the heir dies. Third, families who are prosperous in terms of economics usually give grants to all children in the form of fields and houses.
\end{abstract}

\begin{abstract}
Abstrak: Praktik Hibah sebagai Ahli Waris Pengganti di Kalangan Masyarakat Jawa. Tulisan ini bertujuan mendiskusikan tradisi memberikan hibah sebagai harta warisan, di mana pewaris sendiri belum meninggal dunia, di kalangan Masyarakat Jawa Selesai Langkat. Data dikumpulkan dengan menggunakan metode kualitatif dengan pendekatan fenomenologi. Data dianalisis secara deskriptif. Data dari lapangan dikumpulkan, diolah, direduksi dan ditarik kesimpulan. Tulisan ini menyimpulkan terdapat tiga pola pemberian hibah sebagai pengganti harta warisan. Pertama, harta dihibahkan seluruhnya kepada ahli waris sebelum pewaris meninggal dunia. Bagian pewaris yang masih hidup biasanya disisihkan untuk biaya hidup dan kebutuhannya. Pewaris biasanya tinggal bersama anak ragil (bungsu). Bila ia meninggal dunia, maka anak yang merawatnya inilah yang mewarisi bagiannya. Kedua, harta warisan dibagikan setelah pewaris meninggal dunia. Ketiga, keluarga yang cukup sejahtera dari segi ekonomi biasanya memberi hibah kepada semua anaknya berupa ladang dan rumah.
\end{abstract}

Keywords: Islamic jurisprudence, hibah, substitute heirs, inheritance, Java family 


\section{Introduction}

In Islamic law, mainly in Islamic family law (al-ahwwâl al-syakhshiyyah) ${ }^{1}$ which includes many aspects including family wealth law (amwâl), has set out the inheritance, testament, and hibah, the like relating to acceptance and or granting. ${ }^{2}$ Inheritance as one of the law of wealth in the family, defined as the transfer of the estate of the heirs (the deceased) to his heirs, while inheritance is an object left by a deceased person who belongs to the heirs. ${ }^{3}$ Kompilasi Hukum Islam (KHI) ${ }^{4}$ explain the law of inheritance is a law that regulates the transfer of rights of the owner of heritage (tirkah) hereditary, determines who is entitled to be an heir and what part of each. ${ }^{5}$ This means inheritance is a treasure that is distributed to the heirs after the owner of the property dies.

However, some provisions in the Islamic inheritance law, by some Indonesian Islamic societies are not implemented, either directly or indirectly. ${ }^{6}$ This is supported by the position of KHI as an Indonesia Fiqh. ${ }^{7}$ Directly done by people who do not agree with the division of Islamic inheritance which is equal to 2:1 for men and women. Indirectly, this can be seen with the existence of the practice of giving the estate of heirs by way of 'grant' which is then used as an alternative medium of inheritance distribution.

A grant is a wealth that is distributed to the heirs before the owner dies. In the life of Indonesian Muslim society, many cases of inheritance are distributed to the heirs before the owner dies. Accordingly, the property distributed is in the form of a non-inheritance grant. By this, hibah functioned as a substitute for inheritance.

Moreover, the practice is rung with languages that are easy to understand in the form of certain articles, in the KHI in article $211 .^{8}$ This article becomes the basis or basis

${ }^{1}$ The definition of family law according to Wahbah al-Zuhailî, as quoted by Khoiruddin Nasution, is a law that regulates human relationships with his family starting from marriage to endon the division of inheritance because there are family members who died. Khoiruddin Nasution, Hukum Keluarga (Perdata) Islam Indonesia (Yogyakarta: Tazzafa \& ACAdeMIA, 2007), p. 8.

${ }^{2}$ Ibid., p. 8.

${ }^{3}$ Abdul Ghafur Anshari, Hukum Kewarisan Islam di Indonesia: Eksistensi dan Adaptabilitas (Yogyakarta: Ekonisia, 2005), p. 21.

${ }^{4}$ Here in after referred to as Islamic Legal Compilation (Kompilasi Hukum Islam or KHI).

${ }^{5}$ Kompilasi Hukum Islam, Pasal 171 a.

${ }^{6} J a i h$ Mubarok, Ijtihad Kemanusiaan di Indonesia (Bandung: Pustaka Bani Quraisy, 2005), p. 154.

${ }^{7}$ M. Nur Kholis al-Amin, "Hibah Orang Tua Kepada Anak sebagai Pengganti Waris: Tela'ah Hermeneutika terhadap Pasal 211 Kompilasi Hukum Islam," in al-Ahwâl: Jurnal Hukum Keluarga Islam, Vol. 6, No. 1, 2013, p. 2.

${ }^{8}$ Article $211 \mathrm{KHI}$ "hibah (grants) from parents to their children may be counted as inheritance." 
for the practice of division of inheritance through a grant that has been a tradition in some societies, especially, among the kinship community. ${ }^{9}$ They follow the bilateral flow that is in the line of family following the father and mother line.

The tradition of giving hibah in exchange for inheritance is also prevalent among communities, ${ }^{10}$ especially Javanese Muslim communities. This custom is also believed to be more influenced by the traditions and customs that occur in the Javanese community itself. In other words, the division of inheritance with the influence of Javanese culture is more applied to the people, rather than the religion of Islamic inheritance law. However, with the changing environment and educational development, other cultured communities, Javanese society is likely to experience a change in its traditions. Moreover, Islam itself adopts changes in various forms, including changes in knowledge, behavior and law, as long as not contrary to religious teachings. ${ }^{11}$ Especially when people in this Javanese society coexist with other communities who have traditions and customs those are different from it. Of course, this can affect the original tradition of the community.

In terms of giving hibah as part of inheritance, the Javanese community in Kecamatan Selesai who coexist with the Batak Karo and Malay may be exposed to the tradition of dividing inheritance among Batak people who tend patrilinial, ${ }^{12}$ and also the Malay people who are considered to have a better knowledge of Islam, thus allowing the Javanese people also to influence the implementation of Islamic inheritance law.

This paper wants to know the background of why the Javanese communities in Kecamatan Selesai divide the inheritance through the hibah. This paper also wants to find out how the pattern of distribution of hibah as a substitute for inheritance among

${ }^{9}$ The word kinship is usually translated into kinship or nationality. Another term used to mean kinship is "kekerabatan." Koentjaraningrat, Beberapa Pokok Antropologi Sosial (Jakarta: Penerbit Dian Rakyat, 1977), p. 29.

${ }^{10}$ Badruddin Ibrahim, "Hibah (Gift inter vivos) by Parent in Favour of Some Children to the Exclusion of the Others under Islamic Law," in Arab Law Quarterly, Vol. 31 Issue 1, 2017, p. 54-73. See also, Muliana and Ahmad Khisni, "Akibat Hukum Akta Hibah Wasiat yang Melanggar Hak Mutlak Ahli Waris (Legitieme Portie)," in Jurnal Akta, Vol. 4 No. 4, Desember 2017, p. 740.

${ }^{11}$ Noeng Muhadjir, Filsafat Ilmu: Kualitatif dan Kuantitatif untuk Pengembangan Ilmu dan Penelitian (Yogyakarta: Rake Sarasin, 2006), p. 212-213.

${ }^{12}$ This patrilineal system is in principle a system that draws the father's lineage or the lineage of its male ancestors. This system in Indonesia among others found in the communities in Gayo Land, Alas, Batak, Ambon, Irian Jaya, Timor, and Bali. In a fatherly society it is usually just a boy who is an heir. Because the married woman will follow her husband and enter her husband's family and will be removed from her own family. So, she is not the heir of his parents who died. Boys can inherit from their father and mother and are originally entitled to all the property left by their parents.Tamakiran S., Asas-asas Hukum Waris Menurut Tiga Sistem Hukum (Bandung: Pioner Jaya, 1992), p. 69. 
the Javanese family and the things that affect these patterns. This paper is important given the growing popularity of the hibah institutions offered by the Compilation of Islamic Laws, ${ }^{13}$ as the principles of the implementation of such grants is considered to be a rejection of Islamic inheritance law that distribute the male and female parts $2: 1$. Or the implementation of the hibah in exchange for the inheritance is an exercise of tradition and the sense of justice of the family alone.

This research used qualitative method and phenomenology approach. Data collected by discussion and interview. Interview is done using purposive sampling. The data resources are those have done the practice of hibah and inheritance in their family. Data analysis used descriptive analysis. The data from the field was collected, processed, reduced and then concluded, as used by Miles and Huberman.

\title{
Social Setting of Javanese Community in Kecamatan Selesai
}

Selesai ${ }^{14}$ is one of 23 sub districts ${ }^{15}$ in Kabupaten Langkat. With the number of

\begin{abstract}
${ }^{13}$ Naviri Masma Rahmita dan Rachmad Budiono, "Analisis Kompilasi Hukum Islam Tentang Tolok Ukur Hibah yang Diperhitungkan sebagai Warisan," in Jurnal Cakrawala Hukum, Vol. 8, No. 1, 2017, pp. 75-85.

${ }^{14}$ This area is called Selesai, now Kecamatan Selesai starting from an independent kingdom is not subject directly to other major kingdoms. The kingdom is called Darul Aman Kingdom with the central Government in Hulubalang (now Kelurahan III Kelurahan Pekan Selesai). The Darul Aman Kingdom area covers the area that is currently the District of Sei Bingai, Kuala, Salapian and others. Given the Kingdom of Darul Aman is a kingdom that already has a high and prosperous civilization make other larger kingdoms became interested to control the Kingdom of Darul Aman. As a result, there arose a dispute with the kingdoms, so there was a continuous battle. Since then the Darul Aman Kingdom which was once safe and peaceful, changed into disputes, the word selisih became known to the public. At that time because of this situation, a kind of monument or signpost that read selisih built in Lingkungan VI Pamah Kelurahan Pekan Selesai. When the kingdom of the north who wishes to control the Kingdom of Darul Aman sends his troops under the command of the Elang Panas Commander. The arrival of the Commander of the Elang Panas with his troops is known by the Royal Darul Aman kingdom. The king welcomed with a troop of soldiers led by a Commander named "Ngasah". Considering that the troops led by the Elang Panas had a remarkable ability to fight, the Panglima Ngasah prepared a ruse by preparing beautiful girls to greet the force. The girls burned young corn along the Begumit River. The Elang Panas is attracted to the corn and they eat to their fullest. After that they rest on the place that has been prepared by the beautiful girls on 'daun jelatang nyiru (a kind of leaf that is very itchy and venomous. Because of satiety and fatigue, Elang Panas without thinking straight lay down on the place resting on 'Jelatang Nyiru'. Finally, the whole body of Elang Panas is rash, itchy and sick. In such a situation, the Panglima Mengasah and Darul Aman's troops stormed unexpectedly and caused the Elang Panas army to crumble and the Hot Eagle Commander was killed in the fighting.Some of the surviving survivors of the Brahmin Emperor regarded the Darul Aman Empire as extraordinary, how unbalanced it was to fight, supposedly also the King, Commander, Soldier and his people. They consider their dispute with the Kingdom of Darul Aman to be done (selesai) for their fear. The Darul Aman Kingdom during its heyday also dealt heavily with the problems and disputes that took place within the Kingdom of Darul Aman, and all could be settled peacefully and acceptable to both sides of the conflict. Disputes and issues within
\end{abstract}


villages are 13 villages and 1 (one) kelurahan. ${ }^{16}$ The capital of Kecamatan Selesai is located in Pekan Selesai. People in this sub district are about 31.476. The most densely populated areas are in the villages of Padang Brahrang, Selayang Baru, Selayang and Padang Cermin. Inhabitants of this kecamatan are 50\% Malay, Karo 20\%, Javanese 20\% and, Banjar, China and others $10 \%$. The Javanese spread in almost all villages, especially in plantation areas, but the majority of these tribes exist in Bekulap, Padang Cermin, Lau Mulgap and Padang Brahrang.

The Javanese live side by side with other tribes and inhabitants peacefully. They interact and communicate with Bahasa Indonesia, but among their parents use the Javanese language or interfere with Bahasa Indonesia. People's livelihoods in the villages of Kecamatan generally are in agriculture and plantation. There are few people who become river fishermen among the Malays who live not far from the river. The rest of them are traders, employees, artisans or laborers.

The Javanese people in Kecamatan Selesai adaptive properties so that they can communicate well with neighbors even with different tribes. They live in harmony, work together and help each other as well as a village community that still maintains the values of togetherness. Religion of Javanese community in Kecamatan Selesai is generally Islam, there are few who experience christianization especially that has been contaminated with the life of other tribe community that is non-Islam plus the reason of poverty. But that number is not significant.

Javanese society's education is generally low, but nowadays as the age and education that has reached the outskirts, at least basic education has been accessible to them. Javanese living in villages near highway/highway have education opportunities to the city as they are easier to access school in the city. Religious education for who living in remote areas is accessed from the surau or mushalla they call the Langgar. They also learn the islamic knowledge at the Majelis Taklim. Religious education for children is obtained from an afternoon school or madrasah they call a 'Mastaf' or from a morning school through religious studies. Of course, by taking such education, their religious knowledge

Darul Aman are always settled fairly and peacefully. Therefore, the word "selisih" is changed to "selesai" which is now the name of Kecamatan Selesai. See "Sejarah Singkat," in http:// selesai.langkatkab.go.id/profil/sejarah.html.

${ }^{15}$ Twenty three districts of Langkat district include Babalan, Bahorok, Batang Serangan, Besitang, Binjai, Brandan Barat, Gebang, Hinai, Kuala, Kutambaru, Padang Tualang, Pangkalan Susu, Pematang Jaya, Salapian, Sawit Seberang, Secanggang, Sei Bingai, Sei Lepan, Selesai, Sirapit, Stabat, Tanjung Pura, and Wampu.

${ }^{16}$ The fourteen villages are Bekulap, Kutaparit, Kuala/ Kuala Air Hitam, Lau Mulgap, Mancang, Nambiki, Padang Brahrang, Padang Cermin, Pekan Selesai, Perhiasan, Sei Limbat, Selayang, Selayang Baru, and Tanjung Merahe. 
is very lacking. Fardhu 'ain knowledge is still minimal, moreover for other religious knowledge like zakat or inheritance.

However, the education of Javanese children who are socially and economically are in the higher strata, usually they go to good school for attention from their parents. They studied till college in a university. Or they learn basic religious knowledge to ustad who deliberately invited to Mushalla or to Mosque regularly. Mushalla or Mosque that provides routine recitation is usually once and coordinated by the village head through Pengajian Hidayah. This is part of the government program.

In terms of cooperation within the community of Javanese and other communities have strong ties. Whether is in party events, circumcision, marriage, birth, death, kenduri and others. These adaptive ties make the Javanese society easy to be accepted everywhere, including in the Kecamatan Selesai which in fact is a Malay inhabitant.

\section{Hibah as a Substitute of Heir in Islamic Law}

Al-Qur'an mentions that the term 'hibah' in Q.S. Âli 'Imrân/3: 38. It is told that Zakariya prays to be bestowed a good offsprings. ${ }^{17}$ Postulate that allowed the practice of hibah in the Qur'an: "And give his beloved treasures to his relatives, orphans, the poor, the travelers (who need help)." In a hadith narrated by Abû Hurairah, Rasulullah said: Tahadu wa tahabbu (Please give each other gifts among you all (then) you will love each other).

Hibah has many meaning wether literally or terminology. Some papers have discussed their meaning. All are pointing to the meaning that hibah is a gift or giving that no return after it. ${ }^{18}$ In fiqh the implementation of the grant has harmonious and requirement. According to Jumhur there are four pillars: wâhib (giver); mauhûb lah (recipient); mauhûb (granted goods); shîghah (îjâb and qabûl).

While the grant implementation requirements cover several things. The requirement for the grant-maker that is grant has what is granted; the grant is not a person whose rights are restricted for a reason; the grant is an adult, intelligent and rasyid and without any element of coercion. Requirements for the person given the grant ie; entitled to have and actually exist at the time given a grant, holding a grant over the permission of wâhib. While the terms of goods granted ie there must be a time of grant; in the form of a strong and useful property, belonging to itself, can be possessed of the substance and not related to another place / separately.

${ }^{17}$ From this verse the language hibah is defined as 'giving.' According to the term shariah of Islam, "aqdu yuqîdu al-tamlîk bilâ 'audh hâla akyâti tathawwû'ân" (A contract that makes ownership without a substitute while still alive and voluntary).

${ }^{18}$ Noor Lizza Mohammed Said, et al., "Hibah dengan Syarat Balasan menurut Pandangan Fuqaha dan Kedudukannya dalam Undang-undang Sivil Jordan," in Journal Syari'ah, Vol. 20, No. 3, 2012, p. 309-328. 
The nature of the goods granted for mauhûb (grantee) without any substitute. But legally can be cancelled by the giver. Even if it can be canceled, the withdrawal of property that has been given the law makrûh because it can hurt the recipient of the grant. Therefore, the withdrawal of grant property already granted should be granted by the grantee. ${ }^{19}$ Jumhur Ulama believes that the grant has been given, if it is in the hands of the recipient can not be returned, except the provision of parents to their small children, and even then if not mixed with the rights of others.

Prophet Muhammad strictly forbids withdrawing grants that have been granted unless the parent grant is given to his son, because religion can still tolerate it because in essence the child's property is the property of his parents as well. It is not lawful for a person to give a grant or gift and then withdraw it, except the parent's gift to the child." 20 From the above hadith it can be seen that the grant that has been granted is prohibited to be asked again because it can cause disappointment and hatred. ${ }^{21}$

The wisdom of the implementation of the grant is that it has a social function in the life of the community whether given to individuals or institutions. Another wisdom is to strengthen kinship relationships or shilaturrahîm among family members more broadly fellow humanity and for help in goodness. As the Prophet said, "tahhâhû tahâaddû (Please give each other gifts among you and you will love one another). ${ }^{22}$

In practice, the prophet and his companions in giving and receiving gifts are not only among fellow Muslims but also from or to people of different religions, even with the polytheists. The Prophet never received the gift of the Kisra, and he once permitted 'Umar Ibn Khaththâb to give a shirt to his idolized brother in Mecca.

To distinguish the inheritance, the grant is a gift when the possessed possessions are still alive, while the inheritance is given when the treasure has passed away. Although the timing of the award is different, both have very close relationships, especially the grant is given to the child or heir because it will determine the inheritance if the grant does not have the consent of the heir or at least there is an heir who objected to the grant.

Therefore, there is often a dispute between the heirs; one party is of the opinion that the grant that has been given is different from the inheritance, while the other party (the heirs who do not receive the grant) declares that the grant received is a divided inheritance. Hence, the heirs who have received the grant will not get inheritance anymore or get inherited but the value and amount is accumulated with the grant it has received.

${ }^{19}$ According to the Hanafi, the hibah giver may withdraw his grant, if the grant is not accompanied by a reply or not accompanied by a reward, even though the grant has been received by the granted. Nasrun Haroun, Fiqh Mu'amalah (Jakarta: Gaya Media Pratama, 2000), p. 86.

${ }^{20}$ H.R. Ashhâb al-Sunan dari Ibn 'Abbâs and Ibn 'Umar.

${ }^{21}$ H.R. Abû Dâwûd and Nasầî.

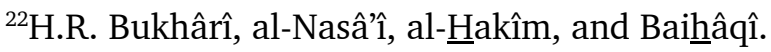


Hibah giving is not allowed to give all to one of the children. Parents should be fair. Had it been given in an unfair way then the grant that had been granted could be withdrawn to be redistributed.

Islamic jurists differ on how to be fair in giving wealth and treatment to children. Whether in fulfilling the sense of justice, the division must be the same or different. Some argue that the gift is the same between boys and girls. But there is also an opinion that boys and girls have different sections. Boys get twice as many from girls as taught in Islamic inheritance. ${ }^{23}$

Some fuqahâ' explain that equating the number or portion is not really an obligation but the law of Sunnah. They say that the hadith which describes the proportion of grant is weak. While the proposed prohibition of granting all the wealth in the form of grants to his children is a strong opinion. Therefore, if the grant is not in accordance with this provision, then the grant is void. In some traditions it is argued that their part is to be likened and it is not justified to give all the property to one of the children alone. If a grant given by a parent to one of his children exceeds the provisions of the inheritance, the grant may be accounted for as an inheritance.

Based on the above description it can be concluded that the actual gift of wealth to children or heirs in general is allowed in Islam, even highly recommended. In other words, it is permissible for the owner of the property to divide his property to his children or his family before he dies, of course by holding on to the principle of justice. In general, grants are more useful than dividing inheritance after the owner of the property dies. The division of property done when the benefactor is still alive is intended to minimize the conflict because it can be done dialogue and deliberation between families.

Speaking of the relationship between hibah in Islamic inheritance law, it is inseparable from the various problems that occur in Indonesia. Of course the social conditions that occur in Indonesia must be different from what happens in other Muslim countries. If the Islamic law is enforced in accordance with what is in the classical fiqh books, then what happens is the synchronization in the process of solving problems related to the Law of Inheritance in Islam?

Problems arise in the distribution of inheritance. The issue between the division of percentage of inheritance between boys and girls is 2:1. As what has been mentioned in the al-Qur'an al-Nisâ' verse 11, in connection with that Munawir Syadzali in the era of the 80s in the context of the actualization of Islamic law, once revealed that many Muslims who are obedient to his religion to distribute their property when still lives to his children without discriminating the sections of the boys and girls so that the inheritance is only a small part. This is nothing but a form of "avoiding (slit)" of the system for inheritance 2 : 1 and more leading to the division of the $1: 1$ inheritance.

\footnotetext{
${ }^{23}$ Ibid., p.185-186.
} 


\section{Hibah as a Substitute for Inheritance in the Compilation of Islamic Law}

In Indonesia's positive law, grants acting as a substitute for inheritance have legalization as outlined in article 211 of the Compilation of Islamic Law. The spirit of the birth of article $211 \mathrm{KHI}$ can be seen from the basic substance of the rules of the chapter, its relevance to Islam that can be seen from the ever-changing and evolving historical perspective and the response of the Muslim generation in viewing the reality of the community. ${ }^{24}$

In Indonesia's positive law, grants acting as a substitute for inheritance have legalization as outlined in Article 211 of the Compilation of Islamic Law. The spirit of the birth of article $211 \mathrm{KHI}$ can be seen from the basic substance of the rules of the chapter, its relevance to Islam that can be seen from the ever-changing and evolving historical perspective and the response of the Muslim generation in viewing the reality of the community. ${ }^{25}$ There are many Indonesian scholars who are reluctant to follow the Islamic inheritance law, but also do not want to be said to violate farâ'id. They seek a way out by sharing wealth with their children with an equally large share of boys and girls as they live as grants. ${ }^{26}$

Attitudes like this according to the KHI based on the habit that is considered positive by the community. It often happens when an unjustly distributed inheritance will cause suffering to certain parties, especially if the settlement to the Religious Courts will surely occur family split. In connection with this 'Umar bin Khaththâb had argued that restore the verdict between relatives alone, so they make peace, because the verdict of the court is very hurtful and cause pain. ${ }^{27}$

One of the considerations in formulating article $211 \mathrm{KHI}$ is by using modification methods and assertiveness firmness for uniformity for the community or law enforcers. This method is adopted in uniforming the practice of grants by way of record, this way also in accordance with the demands of the times and also the needs of "modern" society who tend to obtain legal certainty in a container of state institutions.

Further relation between legal certainty and "grant" in Islam, which does not necessarily require the existence of a deed of grant made by a competent authority, or a recording procedure for obtaining legality in the State institution by reference to Q.S. alBaqarah/2: 228, raises the discourse that the grant or grant, whether grants deemed to be purely grants or grants which are then regarded as substitutes for inheritance, must be done through legitimate recording or acknowledged by the state for the realization of legal certainty, given that the society at that time has been widely practicing ambivalence,

${ }^{24}$ Charles J. Adams, "Islamic Religious Tradition," in Leonard Binder (ed.), The Study of the Middle East: Research and Scholarship in the Humanities and the Social Sciences (Canada: John Wiley and Sons, 1976), p. 31.

${ }^{25}$ Munawir Sjadzali, Ijtihad Kemanusiaan (Jakarta: Paramadina, 1997), p. 8.

${ }^{26} I$ Ibid., p. 62.

${ }^{27}$ M. Yahya Harahap, Hukum Acara Perdata (Jakarta Sinar Grafika, 2006), p. 236. 
such as if solving the inheritance in the Religious Courts and ending in dissatisfaction, then issue the matter to the District Court. Therefore, article $211 \mathrm{KHI}$ when viewed from the legal certainty paradigm, gives fresh wind to the practice of transferring property from parents to their children by way of grant which can then be considered as a substitute for inheritance when the parent (heir) has passed away.

The utilization of the law in article $211 \mathrm{KHI}$ is: (1) With the existence of inheritance system by grant, in Indonesia as a rechtstaat country, ${ }^{28}$ then the beneficiary with the grant may have authentic proof of ownership of inherited property, so as to avoid conflicts over the issue of inheritance rights. (2) As pointed out above, the seizure of inheritance by the heirs can be avoided. (3) The division of inheritance will be obtained equally, ie the daughter can also be inherited according to their rights. No more excuses for women, less or no share of inheritance.

Legal justice through the human benefit of article $211 \mathrm{KHI}$, that Article 211 Compilation of Islamic Law is partly a reflection of Islamic law that has been legalized into positive law to protect the life of Muslim communities in Indonesia who have a unique culture in the issue of distribution of inheritance. It is in accordance with Wael B. Hallaq's statement that there is no doubt that Islamic law today is a significant foundation in reaffirming the Islamic (sharia) identity, not only as a positive legal substance, but also, more importantly as the basis of a cultural uniqueness. In fact, many Muslims today, that in their life with Islamic law is not only limited in legal matters, but also in the matter of psychology. ${ }^{29}$

Thus, Islamic law is a reflection of cultural uniqueness and some of it is contained in positive law in Indonesia. Therefore, legal justice must be adapted to "what is practiced" by society by not releasing the legal aspects of Islamic law itself.

Article 211 of the KHI for Munawir Sjadzali is an act of legal innovation that begins with the implication of non-fulfillment of a sense of justice and an unwillingness to create a benefit if paragraph 17 of the letter an-Nisâ' is actually applied. This is due to the changing position and role of women in society, so that the value and size of justice change. Such changes in legal innovations can be seen, such as the birth of an action by Muslim societies who divide their inheritance before the time comes or distribute it in the form of a new grant in effect when the heir has passed away. ${ }^{30}$ This is the (factor of

${ }^{28}$ Rechtstaat (a state of law) is a state whose governing power is based on law. In a country based on law, the state including the government and other institutions in carrying out any action must be legal and legally justifiable.

${ }^{29}$ Wael B. Hallaq, The Origins and Evolution of Islamic Law (Cambridge: Cambridge University Press, 2005), p. 1.

${ }^{30}$ Mahsun Fuad, Hukum Islam Indonesia: dari Nalar Partisipatoris sampai Emansipatoris (Yogyakarta: LKiS, 2005), p. 210. 
justice) background of the formulation of article 211 KHI. The formulation of the Compilation of Islamic Law, especially article $211 \mathrm{KHI}$ is a form of reform and creation of Indonesian law when faced with social and cultural reality as living law in society. ${ }^{31}$

In other words, article $211 \mathrm{KHI}$ has a content that tends to distribute justice for the heirs, whether it contains the distribution of economic justice or for the maintenance of peace among its children (heirs). This is in accordance with the principle of Islamic inheritance law, namely the principle of balanced justice. ${ }^{32}$

On the other hand, the development and changing needs of the community can be regarded as an impact to formulate article $211 \mathrm{KHI}$ as a container of change of integration between text and context. This is in line with the modern approach to Islamic law in Indonesia lies in the effort to ensure religious law to accommodate and adapt to secular law, especially the substance of law doctrine based on the concept of indigenous peoples' law, which is customary law. Therefore, some provisions in Islamic inheritance law accommodate many of the teachings of customary law, ${ }^{33}$ as contained in article $211 \mathrm{KHI}$.

The legal integration discourse contained in article $211 \mathrm{KHI}$ as law enforcement efforts in Indonesia includes integration of the concept of justice inheritance law, order and legal benefit. This is evidenced by the integration of the concept of distributive justice, cumulative justice and the concept of Islamic justice combined with various Islamic teachings on the application of inheritance, will, benefit, order and grant to avoid the value of injustice in the distribution of the inheritance, so that things have become tradition as a phenomenon of action from various concepts of justice make reference to formulate Article $211 \mathrm{KHI}$.

\section{Hibah as a Substitute for Inheritance among Javanese Family in Kecamatan Selesai Langkat}

\section{The Portion of Inheritance Division}

Javanese community divides the wealth of inheritance either by grant or by way of inheritance after the heir died. Interestingly this treasure both grants and inheritance usually divided by the same amount or almost the same according to the agreement.

This division is done by deliberation and consensus, which can what, how and where. If a grant or inheritance field is given equally broadly, regardless of the count of

\footnotetext{
31 Jalâl al-Dîn bin 'Abd al-Raḩmân bin Abî Bakar al-Suyûthî, al-Asybâh wa al-Nazâ'ir fí alFurû' (Semarang: Toha Putera, n.d.), p. 63.

${ }^{32}$ Amir Syarifuddin, Hukum Kewarisan Islam (Jakarta: Kencana, 2008), p. 24. See also, M. Idris Ramulyo, Perbandingan Hukum Kewarisan Islam dengan Kewarisan Kitab Undangundang Hukum Perdata (Jakarta: Sinar Grafika, 2004), p. 94.

${ }^{33}$ Ratno Lukito, Tradisi Hukum Indonesia (Yogyakarta: Teras, 2008), p. 146.
} 
the plants on it. If in the form of money, then the money is divided equally. Likewise, with other objects. They will count it more or less the same.

This same division is considered more fulfilling to the sense of justice for the parents when he was alive giving grants. Parents usually also give a will or a message that when one day he died treasure divided equally between boys and girls. "...enko nek aku ninggal yo... hartaku iki yo dibagi sama wae ... anak lanang opo anak wedok serupo wae....wong kabeh yo anakku...ya rak tak bedak-bedakne," (later if I have died....my wealth is divided into the same amount to my children ... boys or girls are the same... all are my children...I won't differentiate"), said Mr. S. when asked his opinion about the portion of each boy and girl when he dies someday.

This same division is considered to give the same affection for his children. They do not want to distinguish gifts to their children either men or women either before or after death. Likewise, giving to a child who is considered to be filial or to a child, who is considered naughty, remains the same division. Or for children who are considered wealthy, especially for their own search, or are still considered poor, they make no distinction except between the children who consent to give members of the family with different portions. Or there is one of the family members willing to reduce the portion and be given to other family members willingly and without coercion. For heirs, the children who deserve the inheritance are their undeserved children. The giving of this wealth either in the form of a grant, ie when the heir is still alive or in the form of inheritance, that is when the deceased has no difference in practice. They keep sharing it equally.

\section{Hibah or Inheritance is the Same}

For the people of Java in Kecamatan Selesai Langkat, grants and inheritance are the same. They do not question whether what is given to them is in the form of a grant or an inheritance. They also do not question the naming. When asked about what they understand with the term in general they do not understand the meaning of both in particular. But they only understand that grants are given before their parents die and inheritance is given to them after the parents die. But for them it does not matter especially when their portion is ultimately the same between men and women.

They say they feel grateful to have a share of inheritance, as they call it (even though the treasure is basically divided by grants). They did not question whether it was an inheritance or a grant. For them, it's no matter.

The Javanese people kecamatan Selesai in this case, avoiding conflict with other members of the family is a big goal. According to them the treasures can be sought. There is no need to have a conflict, since the property they are fighting for is their parent's. 
Generally, they tell how hard their parents work to earn money and the wealth to raise them. So, when the parents passed away, no reason for them to quarrel or fight each other. For the sake of their parent happiness in the hereafter, they act to be peaceful.

Apparently, this awareness of harmony and family harmony is one of the foundations for Javanese sub-districts to share inheritance or grants with equal portions. They on this basis also, do not question whether the property is given in the form of a grant or in the form of inheritance. On the other hand, this may be supported by a stereotype that may be true that Javanese have an attitude and choose "nrimo" then conflict.

\section{Giving Hibah for a Single Parent}

In fact, some Javanese families whose parents had died, had different patterns of property distribution, but still used the grant as a way of dividing property. The wealthare not shared or granted at all as long as both parents are alive. Then after one of his parents died, for example his mother's first or his father first died, then there are several ways of dividing the treasure. First, the treasure is distributed by way of a grant entirely to the heirs before the remaining heir dies. The remaining heirs are usually set aside for living expenses and their needs. The heir is usually living with one of the children, usually a child of ragil (youngest). When he dies, then the child who took care of this is what inherited the heirs earlier. In general, such a division is agreed upon by other family members. Second, the wealth of one of the first heirs passed away first. The first is divided into two treasures. The part of the deceased heirs is half of the existing treasures taken and divided as an inheritance to the heirs and to their spouses who are also the heirs.

The surviving heirs usually have half of the treasures plus the inheritance. Up to this point, a living heir exists that shares some of his possessions as a grant to the heirs and he only takes as many places as he needs to meet his needs in the rest of his life. In such circumstances the host house is usually not shared first. This is what happens to the division of inheritance carried out in the $\mathrm{S}$ and $\mathrm{R}$ families, families who are seen to understand religion and want to ask about how the division of inheritance to people who are considered to understand.Third, if one of their parents passed away the estate is not distributed first. Treasures are managed and enjoyed the results together with existing parents and other family members. If family members do not feel the need to share the results, they can simply refuse.

The main house is usually occupied the youngest child, especially if the youngest child is female. The remaining parents usually come and live with the youngest child in the main house. Later when their remaining parent dies then the property is divided equally portion. However, what often happens is before the remaining parent dies, the inheritance of the deceased heirs and the surviving parent's treasure divided by the same portion of the grant. The living parent will live with his youngest child in the host house at 
the cost of living from his grant. Later when he died the grant will be owned by the youngest child who took care of him.

This is done and generally other family members agree. According to them such things need not be questioned, because the property is the nature of the property of parents because of parents who seek, so not a child's property. The child can find his own property. This happens to families of $\mathrm{N}$ and $\mathrm{S}$.

Interestingly when the division of treasures in the form of fields and rice fields they precede the girls to get a position in front of close to the highway while those who are eldest given the farthest part with the position of the highway. The division that they do also does not pay attention to whether he is male or female, but clearly, they are conducting deliberation and consensus in peace and feel they have obtained justice

\section{Giving Inheritance without Hibah}

Among the Javanese families in Kecamatan Selesai Langkat who have better religious knowledge, usually do the division of inheritance after the heir died.This pattern of division is a little happening considering, of course not all Javanese people have good religious knowledge and not all Javanese families who have knowledge of religion well do the division of inheritance by way of pure Islamic inheritance.

Generally, they understand of Islamic Inheritance but still tend to do hibah giving before the heir passed away and they divide in the same portion. They have the reason to do so since their parent have their sentence to their children; otherwise they have another agreement among them. This is as happened in $\mathrm{N}$ and $\mathrm{N}$ family.

\section{Giving Hibah and Inheritance}

In the properous Javanese family, the pattern of this pattern of property sharing combines patterns, hibah and inheritance. Rich parent will give hibah to their children especially after marriage.

Hibah can be a house either purchased or built and added a business or fields such as rice fields and palm as their business after marriage. This grant is usually given to every married child. Even though, their parents are still young and healthy.

When their parents pass away, then the treasure that becomes a relic of the parents becomes an inheritance. But interestingly, the property granted to the heirs before the heir dies is accumulated in a matter of inheritance. Also, the division of such property still counted as a share of equal portion between boys and girls. Patterns of distribution like this, as happened to families $\mathrm{G}$ and $\mathrm{R}$. 
Therefore, the practice of wealth dividing by using hibah as a substitute for inheritance as above can be concluded that this tradition gives a specific term, that is an emerging term that is the use of grants as an engineering to reject the Islamic inheritance law, especially there a conflict with the habits of Indonesian society. This is what Munawir Syadzali called Hiyâl al-Syar'iyyah. ${ }^{34}$

Interestingly, the amount of hibah those given to the male and female are same. This is suitable for the Islamic teaching. For, different amount and giving hibah between male and female is considered as to be null. Moreover the amoun of hibah exceed from the permissible limit amount. ${ }^{35}$

The word al-hiyâl is a plural form of the word al-hilah which means a deception, wit, deceit, or reason that is sought to escape from a burden or responsibility. Or in other languages can be called by term 'kilah' (slit). ${ }^{36}$ Hiyâl al-syar'iyyah takes place in a grant practice, one of which is the willingness of the grant giver (wahib) to grant his / her wealth to the grantee in the amount he wishes to avoid other legal provisions limiting the amount of property which may be received by the grantee.

Muhammad Said al-Asmawi reveals this, and the practice of this sort when it comes to the Court will cause many difficulties. Muhammad Âmîn al-Asymâwî gives advice to parents who want to give equal rights for their children using the institution of endowments waqf (waqf family). Through waqf the property of origin should not be transferred its ownership, but the result is enjoyed equally by all heirs. ${ }^{37}$

In his other writings, Munawir argues that such a grant is an indirect violation of the Qur'anic provisions. It is true that doing the grant is also a religious teaching but doing the grant in such a spirit (for boys and girls to get the same portion) is whether it is true according to the religious psyche. Or is it a legal deed in the eyes of religious teachings. ${ }^{38}$

Majid Khadduri when describing the difference between substantive justice and procedural justice, assessing the deed in the form of a grant for wanting to give the treasure in an amount greater than the amount allowed in the inheritance law (farâiidh) is not an illegal act. This is a legal fiction or legal fiction that is actually subordinated to substantive justice. On the basis of this kind of thinking according to Khadduri the scholars

${ }^{34}$ Mukhtar Zamzam, "Hiyâl al-Syar'iyah dalam Praktik Hibah dan Wasiat," paper in Rakernas MARI, Jakarta, 2011, p. 2.

${ }^{35}$ Dewi Sartika Utami, "Akibat Hukum Pemberian Hibah yang Melebihi Batas Legitime Portie: Analisis Kasus Putusan Pengadilan Negeri Nomor 109/Pdt.G/2009/Pn.Mtr. mengenai Hibah," in IUS: Jurnal Kajian Hukum Islam dan Keadilan, Vol. 4, No. 2, Agustus 2016, p. 102.

${ }^{36}$ Departemen Pendidikan Nasional, Kamus Besar Bahasa Indonesia (Jakarta: Balai Pustaka, 2005), p. 567.

${ }^{37}$ Muhammad Saî̀d al-Asymâwî, Problematika \& Penerapan Syariat Islam dalam UndangUndang, transl. Saiful Ibad (Jakarta: Gaung Persada Press, 2005), p. 85.

${ }^{38}$ Zamzam, "Hiyâl asy-Syar'iyah dalam Praktik Hibah dan Wasiat," p. 6. 
in the Hanafi school allows the use of hilah in the framework of wise legal fiction (wisdom legal fiction), not hilah in avoiding the religious obligations of absolute justice. ${ }^{39}$

According to A. Qodri Azizy, the use of grant institutions in the distribution of inheritance is quite common among Islamic societies in Indonesia. Qodri Azizy considers it a part of the practice of al-ahkâm al-wijdâniyah as introduced by Muhammad Salam Madkur. Al-Ahkkâm al-wijdâniyah is a law of conscience, which holds to the principle of mutual relief (an tarain) between fellow heirs so that the heirs do not need to go to court. ${ }^{40}$ This is one way to combine Islamic law and social context. ${ }^{41}$

As discussed in the previous discussion, in the KHI, a grant relationship with inheritance is contained in Article 211, namely:" Hibah (grant) from parents to their children can be counted as inheritance." Relating to the legality of giving hibah itself, there are not sufficient basis in doing it. That happens as it is, getting along with social change and development. ${ }^{42}$

In this case, it can be analyzed further, then Article 211 Compilation of Islamic Law contains the aspect of 'urf, because after looking at the passage, whether it is al-Qur'an or Hadith, there is no passage indicating about the calculation of grant from parent to child as inheritance.

Thus, that the provision of Article 211 of the Compilation of Islamic Law concerning the grant of parents to their children, can be counted as an inheritance. The grant is a custom that has been rooted and has been accepted by the people of Indonesia. This kind of custom according to the rules of Islamic Law is called 'urf. What is meant by 'urf is anything that is known to man, which has become a habit or a tradition, whether it is a word, a deed or in relation to abandoning certain deeds? 'Urf is also called 'adat (custom). The notion of applying Islamic law based on adat lawor urf has been boasting by Hazairin. He maintains that as long as urf or adat law is getting along with Islamic Law, Islamic law accepts it as Islamic law. ${ }^{43}$

Ahmad Azhar Basyir in the question of relevance 'urf with al-Qur'an or hadith, explains that the condition of 'urf can be used as a source of law ijtihadiyah one of them

${ }^{39}$ Majid Khadduri, Teologi Keadilan Perspektif Islam, transl. Mochtar Zoerni and Joko S. Kahhar (Surabaya: Risalah Gusti, 1999), p. 124.

${ }^{40}$ Zamzam, "Hiyâl Asy-Syar 'iyah dalam Praktik Hibah dan Wasiat," p. 9.

${ }^{41}$ Mahsun Fuad, "Pendekatan Terpadu Hukum Islam dan Sosial: Sebuah Tawaran Pembaruan Metode Penemuan Hukum Islam," in Al-Mabsut: Jurnal Studi Islam dan Sosial, Vol. 3, No. 1, 2012.

${ }^{42}$ Abdul Bari Awang and Amilah Awang Abd Rahman, "Are Parents Free to Bestow Their Wealth into Their Children? A Justice Discourse on Equality and Justice in Hibah," in Shari'ah Journal, Vol. 22, No. 3, 2014, p. 407-426.

${ }^{43}$ Sukiati, "Hazairin's Legal Thought and his Contribution towards the Indonesian Legal System," in Journal of Indonesian Islam, Vol. 6, No. 1 Juni 2012, p. 93-124. 
is if 'urf is not contrary to nas (Quran or hadith). Therefore, to assess whether something is against the nas or not, a careful review is necessary. Because there is a possibility, something cursory seems to be in conflict with the texts, but after being exposed to various texts in some ways; it can be made an approach between 'urf applicable to existing Nash terms, without showing any irreconciable contradictions. ${ }^{44}$

Hazairin offers the same idea. He says that Adat law will be associated as Islamic Law when adat law is not contradicted to Islamic law. This idea is named as 'receptie theory'. Using this theory, he calls "pembaharuan hukum Islam," or Islamic legal reform to Indonesia Legal System. Relating to hibah as a substitute to heirs, he maight maintain that as long as it is getting along to Islamic law and not contradicted to shariah law, hibah is accepted. ${ }^{45}$

In relation to the issue article $211 \mathrm{KHI}$ has provided a solution, namely that the grant given by parents to their children can be counted as an inheritance. The notion of "can" in the passage does not mean imperative (a must), but it is one of the alternatives that can be taken to resolve the inheritance dispute. Throughout the heirs no one questions the grant that some of the heirs have received; the inheritance that has not been granted may be distributed to all heirs according to their respective portions.

But if there are some heirs, then the grant can be calculated as inheritance, by calculating the grant received by the portion of inheritance that should be received, if the grant has been received is still less the portion of inheritance then live add to its shortcomings, and if it exceeds the portion of inheritance then the excess grant can be withdrawn to the heirs that lack of portions. ${ }^{46}$

In practice, however, much of the inheritance exercised by the testator in this case is the parent to the child when the parent is alive by using hibah as an alternative. This has been legalized by the formulation of Article 211 in the Compilation of Islamic Law, which seems to provide legalization of inheritance practices by bumping into the orthodoxy of a standard Islamic inheritance concept. ${ }^{47}$

\section{Conclusion}

A grant is a gift when possessed possessions are still alive, while inheritance is given when the one who has the property has died. Although the time of the award is

${ }^{44}$ Ahmad Azhar Basyir, Hukum Adat Bagi Umat Islam (Yogyakarta: Nur Cahaya, 1983), p. 31.

${ }^{45}$ Sukiati, "Hazairin's Legal Thought," p. 93-124.

${ }^{46}$ Zainuddin, Pelaksanaan Hukum Waris di Indonesia (Jakarta Sinar Grafika, 2008), p. 25.

${ }^{47}$ Sakirman, "Telaah Hermenutika Pasal 211 KHI dalam Memberikan Access to Justice Terkait Hibah dan Waris," in Jurnal Konstitusi, Vol. 15, No. 1, Maret 2018, p. 114. 
different, the two have a very close relationship; especially the grant is given to the child or heir because it will determine the inheritance if the grant does not have the consent of the heir or at least there are heirs who object to the grant.

The religious leaders and local community leaders should be able to give counseling and understanding about the inheritance of Islam, in addition citizens are also required to be active in studying and understanding the Islamic inheritance law based on the provisions of science farâ'id in Islam. As a Muslim should be able to learn and practice the lesson of Islamic inheritance law in accordance with the provisions of Islamic shari'ah.

\section{References}

Adams, Charles J. "Islamic Religious Tradition," in Leonard Binder (ed.). The Study of the Middle East: Research and Scholarship in the Humanities and the Social Sciences. Canada: John Wiley and Sons, 1976.

Al-Amin, M. Nur Kholis. "Hibah Orang Tua Kepada Anak Sebagai Pengganti Waris: Tela'ah Hermeneutika terhadap Pasal 211 Kompilasi Hukum Islam," in Al-Ahwâl: Jurnal Hukum Keluarga Islam, Vol. 6, No. 1, 2013.

Al-Asmawi, Muhammad Said. Problematika dan Penerapan Syariat Islam dalam UndangUndang, transl. Saiful Ibad. Jakarta: Gaung Persada Press, 2005.

Al-Suyûthî, Jalâl al-Dîn bin 'Abd al-Rahmân bin Abî Bakar. al-Asybâh wa al-Nazhâ'ir fí alFurû́. Semarang: Toha Putera, t.t.

Anshari, Abdul Ghafur. Hukum Kewarisan Islam di Indonesia: Eksistensi dan Adaptabilitas. Yogyakarta: Ekonisia, 2005.

Awang, Abdul Bari, and Amilah Awang Abd Rahman, "Are Parents Free to Bestow Their Wealth into Their Children? A Justice Discourse on Equality and Justice in Hibah," in Shari'ah Journal, Vol. 22, No. 3, 2014.

Basyir, Ahmad Azhar. Hukum Adat Bagi Umat Islam. Yogyakarta: Nur Cahaya, 1983.

Departemen Pendidikan Nasional. Kamus Besar Bahasa Indonesia. Jakarta: Balai Pustaka, 2005.

Dewi Sartika Utami, "Akibat Hukum Pemberian Hibah yang Melebihi Batas Legitime Portie: Analisis Kasus Putusan Pengadilan Negeri Nomor 109/Pdt.G/2009/Pn.Mtr. mengenai Hibah," in IUS: Jurnal Kajian Hukum Islam dan Keadilan, Vol. 4, No. 2. Agustus 2016.

Fuad, Mahsun. "Pendekatan Terpadu Hukum Islam dan Sosial: Sebuah Tawaran Pembaruan Metode Penemuan Hukum Islam," in Al-Mabsut: Jurnal Studi Islam dan Sosial, Vol. 3, No. 1, 2012. 
Fuad, Mahsun. Hukum Islam Indonesia: dari Nalar Partisipatoris sampai Emansipatoris. Yogyakarta: LKiS, 2005.

Hallaq, Wael B. The Origins and Evolution of Islamic Law. Cambridge: Cambridge University Press, 2005.

Harahap, M. Yahya. Hukum Acara Perdata. Jakarta Sinar Grafika, 2006.

Haroun, Nasrun. Fiqh Mu'amalah. Jakarta: Gaya Media Pratama, 2000.

Ibrahim, Badruddin. "Hibah (Gift inter Vivos) by Parent in Favour of Some Children to the Exclusion of the Others under Islamic Law," in Arab Law Quarterly, Vol. 31 Issue 1, 2017.

Khadduri, Majid. Teologi Keadilan Perspektif Islam, transl. Mochtar Zoerni and Joko S. Kahhar. Surabaya: Risalah Gusti, 1999.

Khisni, Muliana and Ahmad. "Akibat Hukum Akta Hibah Wasiat yang Melanggar Hak Mutlak Ahli Waris (Legitieme Portie)," in Jurnal Akta, Vol. 4 No. 4, Desember 2017.

Koentjaraningrat. Beberapa Pokok Antropologi Sosial. Jakarta: Penerbit Dian Rakyat, 1977.

Lukito, Ratno. Tradisi Hukum Indonesia. Yogyakarta: Teras, 2008.

Mubarok, Jaih. Ijtihad Kemanusiaan di Indonesia. Bandung: Pustaka Bani Quraisy, 2005.

Muhadjir, Noeng. Filsafat Ilmu: Kualitatif dan Kuantitatif untuk Pengembangan Ilmu dan Penelitian.Yogyakarta: Rake Sarasin, 2006.

Nasution, Khoiruddin. Hukum Keluarga (Perdata) Islam Indonesia. Yogyakarta: Tazzafa \& ACAdeMIA, 2007.

Rahmita, Naviri Masma, and Rachmad Budiono. "Analisis Kompilasi Hukum Islam Tentang Tolok Ukur Hibah yang Diperhitungkan Sebagai Warisan," in Jurnal Cakrawala Hukum, Vol. 8, No. 1, 2017.

Ramulyo, M. Idris. Perbandingan Hukum Kewarisan Islam dengan Kewarisan Kitab Undangundang Hukum Perdata. Jakarta: Sinar Grafika, 2004.

S., Tamakiran. Asas-asas Hukum Waris Menurut Tiga Sistem Hukum. Bandung: Pioner Jaya, 1992.

Said, Noor Lizza Mohammed. et al., "Hibah dengan Syarat Balasan Menurut Pandangan Fuqaha dan Kedudukannya dalam Undang-undang Sivil Jordan," in Journal Syari'ah, Vol. 20, No. 3, 2012.

Sakirman. "Telaah Hermenutika Pasal 211 KHI dalam Memberikan Access to Justice Terkait Hibah dan Waris," in Jurnal Konstitusi, Vol. 15, No. 1, Maret 2018.

Sjadzali, Munawir. Ijtihad Kemanusiaan. Jakarta: Paramadina, 1997.

Sukiati. "Hazairin's Legal Thought and his Contribution towards the Indonesian Legal System," in Journal of Indonesian Islam, Vol. 6, No. 1 Juni 2012. 
MIQOT Vol. XLII No. 1 Januari-Juni 2018

Syarifuddin, Amir. Hukum Kewarisan Islam. Jakarta: Kencana, 2008.

Zainuddin. Pelaksanaan Hukum Waris di Indonesia. Jakarta Sinar Grafika, 2008.

Zamzam, Mukhtar. "Hiyâl al-Syar'iyah dalam Praktik Hibah dan Wasiat," Makalah Rakernas MARI, Jakarta, 2011. 